\title{
External Debts and Economic Growth in Nigeria: An Empirical Study Using Autoregressive Distributed Lag Model
}

\section{Olasode OS and Babatunde TS*}

Department of Economics, Lagos State University, Yaba, Lagos, Nigeria

\begin{abstract}
This paper models some economic theories which explained the casual relationship between accumulated funds/ loans from external sources (external debts) and economic growth with a more focus on Nigerian economy, as it is a usually trend for debts of third world and developing countries debts profile to be high, and this case is also the same with Nigeria as the country debts profile is on the increase once more after the debt cancellation of 2005 by the Paris Club of creditors. Also in the innovation by this study is the used of the Autoregressive Distributed Lag (ADL) model to capture the effect of externals debts on viability and growth Nigerian economy from 1984-2012. The preliminary and normality tests shows that the variables are positively skewed but are not normally distributes, while the econometric tests of Stationarity (Unit Root Test) and Co-integration Tests conform that all the variables exhibit Stationarity at first differenced and the existence of long-run relationship between the variables was also confirmed by the Johansen Cointegration test carried out. The result from the ordinary least squares method used confirms the existence of a dual behaviour as the lag 1 of external debts has positive while external debts of present year posed a negative effect on the performance of the economy. The recommendations are Nigeria government should ensure that debts incurred are channel towards productive uses and debt management office of the government should strengthen its plans and foster appropriate use of loans in the critical area the need for is identified.
\end{abstract}

Keywords: External debts; Economic growth; Autoregressive distributed lag; Nigeria government; Oil price shock; Paris club

\section{Background of the Study}

It is a globally acknowledged fact and that most third world and developing countries are faced with the scarcity of funds to finance major infrastructure projects in their countries. As such, they usually have to seek for funds from internal and external sources to supplement their revenues from taxes and earnings from other means, which are usually low when compare with other developed nations. As a result of this situation, most developing have to hype of debts which always serve as barrier to economic growth and welfare in this parts of the world. Since accumulating debts for the developing countries is situation they must leave with to achieve enhanced infrastructural facilities, most development economist are now advocating for "favourable debts". A Favourable debt is one whose the capital acquired has the potentials of high leftover after deducting the cost of loan. In this situation, the debts will be financing economic growth, increasing the infrastructural capacity and expanding output of the borrowing country [1].

This situation is also obvious in developmental strategies and plans of most sub-Saharan African countries where this financing of these developmental plans are heavily tied to foreign loans, a typical example is the $1^{\text {st }}$ to $3^{\text {rd }}$ development plans of Nigeria [2]. It is as a result of this and other luxury-seeking attitude of leaders in these countries that have made the countries to have a heap of external debt to a level that it is unsustainable, as they never propel the needed economic growth that could finance the repayment or to service them. The Nigeria scenario before Debt forgiveness of 2006 is a vivid example, with an inconsequential debt of $\$ 1$ billion in 1971, to accumulate up to $\$ 40$ billion towards the end of 2005 , with over $75 \%$ from the Paris Club alone. The case is still obtainable today, as the country has since 2010 has been financing her budget deficit with loans from various multinational agencies, even with increase in global Oil price.

This situation call for a proper rethink and redirection in the debts management policy of the federal government, as the country's debt stock before the 2006 debt cancellation was above the sum of 18 other poor countries (14 of them African countries) categorised as HeavilyIndebted Poor Countries (HIPCs). As the 18 HIPCs countries who secured the total debts cancellation are and their total debts is $\$ 40$ Billion- Benin Republic, Bolivia, Burkina- Faso, Ethiopia, Ghana, Guyana, Honduras, Madagascar, Mali, Mauritania, Mozambique, Nicaragua, Niger. Rwanda, Senegal, Tanzania, Uganda and Zambia (Semenitari, 2005).

Just like most Oil nations expect few, Nigeria's history of heavy debt burden started around late 1970s to early 1980's, which saw a sharp decline in government revenue from Oil and need to finance the flamboyant lifestyle of governments in Nigeria. These twin reasons made it impossible for the Babaginda's regime to refuse the adoption of the IMF's Structural Adjustment Programme (S.A.P) proposed to the country in 1986, as adoption of this policy will facilitate releasing of loans by this institution to the government to finance flamboyant lifestyle that has a correlation with economic growth. It due to this that this period, 1986-1993, witnessed the peak of external debts in the country.

This huge debt actually made it impossible for succeeding governments to provide as debt servicing and repayment usually cart away over $10 \%$ of the country before the 2006 , and the same situation is obtainable now. With the recent recourse to external debt by the present administration both in lump sum and concessional agreement made the study is a vocal point now, which is determining the role of external

*Corresponding author: Babatunde TS, Department of Economics, Lagos State University, Yaba, Lagos, Nigeria, Tel: 2349036394764; E-mail: acadamician4best@yahoo.com

Received May 17, 2016; Accepted June 16, 2016; Published June 23, 2016

Citation: Olasode OS, Babatunde TS (2016) External Debts and Economic Growth in Nigeria: An Empirical Study Using Autoregressive Distributed Lag Model. Bus Eco J 7: 239. doi: 10.4172/2151-6219.1000239

Copyright: (c) 2016 Olasode OS, et al. This is an open-access article distributed under the terms of the Creative Commons Attribution License, which permits unrestricted use, distribution, and reproduction in any medium, provided the original author and source are credited. 
debts in propelling economic using the Autoregressive Distributed Lag, as also to provide answers to the effect of previous economic growth level on present and as well determine the impact of various years loans on the present economic performance of the country. It must be noted that various studies on external debts and economic growth have only examined the casual relationship, while using this methodology is innovation by this study to broaden the understanding of the workings of external debts in a country. So that the policy makers in charge debts management can effectively determine the effect of a proposed debts on the country's economic prosperity.

\section{Theoretical Framework}

The main aim of this empirical investigation is to determine the relationship between external debt and economic growth. According to Sala-i-martin, "economic theories are not enough to pin point the exact determinants of growth. As a solution for this problem they suggest a cross-sectional regression model of the form:-

$$
\gamma=\alpha+\beta 1 \times 1+\beta 2 \times 2+\ldots+\beta n \times n+\varepsilon .
$$

Where $\gamma$ is the vector of the rates of economic growth, and $x 1 \ldots$, $\mathrm{xn}$ are vectors of potential explanatory variables which can vary from researcher to researcher." "The methodology usually used by empirical growth analysts consists of simply "trying" the variables that are thought to be potentially important determinants of Growth".

Based on the above suggestions, Dejere and Persson used the model below which is a modification of Solow model in their study of effect of external debts and economic growth;

yit $+1-$ yit $={ }_{\beta} 0+{ }_{\beta} 1$ Int GDPi $0+{ }_{\beta} 2$ INVit ${ }_{\beta} 3$ nit ${ }_{\beta} 4$ TBit ${ }_{\beta} 5$ DSEXit ${ }_{\beta} 6 \mathrm{E}$ DYit $+\beta$ 7NTDSit $+\beta$ it

The study use log of INTGDP (case for convergence), Growth rate of investment, Population growth rate and trade balance mainly from Solow's growth model; and the debt burden measuring variables: the ratio of external debt to Gross national income, debt service export ratio and net total debt service to investigate the exact relationship between external debt and economic growth in developed and developing countries using a panel data.

Thus, this study adopts this model with introduction of autoregression of GDP and External Debts in order to capture the long-run impact of external debts on productive activities in Nigeria:

$$
\begin{aligned}
& G D P_{t}=a_{1}+a_{2} G D P_{t-1}+a_{3} E X T_{t}+a_{4} E X T_{t-1}+e \\
& G D P_{t}: \text { Gross Domestic Products } \\
& G D P_{t-1}: \text { Gross Domestic Products for previous year } \\
& E X T_{t}: \text { External Debts for present year } \\
& E X T_{t-1}: \text { External Debts for previous year }
\end{aligned}
$$

\section{Methodology}

\section{Nature and source of data}

The data used were gathered from secondary sources. The major sources of data collected in this study are documented materials sourced from journals and reports of the government or her agencies. Therefore, the basic sources of data for this study are CBN statistical Bulletin 2012, Nigerian Bureau of Statistic and Annual Budgets form the Nigeria Budget Office form 1983-2012.

\section{Test of stationary}

A stochastic process is said to stationary if its mean and variance are constant overtime and the value are auto-covariance between the two times period depends only on the distance or lay between the two time periods and not the actual time at which the covariance is computed. In other word, a stationary stochastic process is one with constant mean, variance and covariance. Hence, stationarity test is carried out to verify whether a time series is stationary or time-invariant so as to avoid a spurious regression.

The Augmented Dickey-Fuller (ADF) and Phillips-Perron (PP) unit roof tests will be employed. The choice of two tests to ensure a more robust test as they are some anomalies associated with the conventional Augmented Dickey-Fuller (ADF) test which The PhillipsPerron test is devoid of, and also the Phillips-Perron test use nonparametric statistical methods to take care of the serial correlation in the error terms without adding lagged difference terms. This test is specified thus:

$\Delta \mathrm{Y}_{\mathrm{t}}=\delta+\alpha \Delta \mathrm{Y}_{\mathrm{t}^{-}{ }_{1}}+\mu_{\mathrm{t}}$

Where $\Delta=$ difference operator

$\mathrm{Y}_{\mathrm{t}}=$ Time series

$\mu_{\mathrm{t}}=$ Pure white noise.

Under the null hypothesis that $\alpha=1$ for stationarity, we use the ADF and PP tests statistics to verify the presence of unit root in the series.

\section{Test of cointegration}

In Economic and econometric analysis, two or more variables will be co integrated if they have a long term, or equilibrium, relationship between or among them. Individual time series in a model may be spurious but their linear combination may not, for this purpose cointegration test is conducted to confirm the existence of a long run linear relationship between time series variables.

To identify the number of cointegrating vectors, Johansen's methodology uses two different test statistics namely the trace test statistic and the maximum Eigen-value test statistic. The trace statistic tests the null hypothesis that the number of distinct cointegrating relationships is less than or equal to ' $r$ ' against the alternative hypothesis of more than ' $r$ ' cointegrating relationships, and is defined as:

$$
\lambda_{\text {trace }}(r)=-T \sum_{j=r+1}^{p} \dot{n}\left(1-\lambda_{j}^{\wedge}\right) .
$$

Where

$$
\lambda_{j}^{\wedge}=\text { the eigenvalues }
$$

$\mathrm{T}=$ total number of observations.

The maximum likelihood ratio or put another way, the maximum Eigen-value statistic, for testing the null hypothesis of at most ' $r$ ' cointegrating vectors against the alternative hypothesis of ' $\mathrm{r}+1$ ' cointegrating vectors, is given by:

$$
\lambda_{\max }(r, r+1)=-\operatorname{Tin}\left(1-\lambda_{r+1}^{\wedge}\right) .
$$

Johansen (1988) argues that, $\lambda$ trace and $\lambda \max$ statistics have nonstandard distributions under the null hypothesis, and provides approximate critical values for the statistic, generated by Monte Carlo methods. 


\section{Literature Review}

Foreign debt, in most development literature, is considered one of the viable means of financing infrastructural developments in most economies especially third world and developing countries. This fate is expected as most developing countries are usually faced scarcity of capital and low national savings, and thus, the need to acquire funds from external sources became the next option to finance their infrastructural need. It is a result that these countries are said to be increasing capacity and expanding outputs with the aid of foreign savings. Many theories on debts as its use as developmental tools have been propounded while in the contrast other theories have also shown the negative effect of external debts. One of such theories in support of external debts accumulation is the dual-gap analysis/model which prophesized that development is a function of investment level and that such investment requires domestic savings. The theory stated that most times, this domestic savings are not usually sufficient to ensure that development take place, thus, countries resort to obtaining funds from abroad to support the domestic savings. Furthermore, the theory explain that the need level of external fund sought funds mean equilibrate the excess of import over export, this is the basic assumption of the dual gap theory.

Also, the theory of the 'growth-cum-debt' also addresses the issue of debts in relation to how it affects economic activities. The preposition of this theory is placed on the fact foreign borrowing should only be for investment purposes, i.e. to fill the gap left by insufficient domestic investment and savings. The model also explains the debt carrying capacity of a country can be determine in terms of the benefits and costs of borrowing in the process of economic growth. The model argument is that a country will maintain its capacity to service her debts provided that the debts accumulated is contributing significantly to overall to growth. In order to ascertain this fact, a 'debt cycle' is proposed, in which the behaviour of capital flows (debts) are capture and effective monitoring of the processes the debts are instilled which are closely associated with economic growth and development goals of the country.

The advantage of this model is that its summaries the whole debt to growth process and concluded that any debt strategy/framework will be workable when it is sufficiently improve economic activities of the country in question. In respective of the merit of this model in a its simple framework, its deficiency lies in the lack of theoretical basis for its savings-investment gap. Since, all loans to a country will be provided in a foreign currency and it requires the same foreign currency for repayment, which may leads to overpayment and devaluation of the debtor's currency, explain this transformational process, the model was also silent on it. In theoretical explanation of foreign debts and economic activities is the "Debt Dynamics" which states that since the solvency of a country in relation to external debts is associated with the rate of growth of the real interest rate of the debts and the GDP. Under this approach, the government can be considered to be operating within its budget constraint as long as the expected fiscal policy stance keeps the debt-to-GDP ratio on a stable (or declining) path. Similarly, Eaton defined debt dynamics as the condition that 'debt in any period cannot exceed the present discounted value of the borrowing country's stock of wealth, or future income stream', he therefore suggests that 'all sovereign borrowers are probably solvent in the sense that the discounted present value of their national resources exceeds the value of their national debt.

Many empirical studies have investigated the effect of external debt on economic growth and development, some end up finding a negative impact on economic growth while others do not find any significant relationship between economic growth and external debt. These studies focused on empirical assessment of external debt on per capita GDP, real GDP, GDP growth rate, long-term consumption pattern and capital formation as a precursor for economic growth. As a result of the mix findings of these studies, it is difficult to state equivocally that external debt has positive, negative or any significant impact on economic growth and development.

A review of the negative relation put the study of Pattillo [1], which shows that stock of debt is the reason for a slow growth, while others found that both the debt burden and the debt service obligations squeeze investment and the economic performance in country [3].

Also, an attempt to clearly state the relationship between external debt and economic growth, for Asian and Pacific Countries over a period of 1970-1988 was under study by Chowdhury 1994. His study found both external debts (public and private) has a relatively very small impact on GNP and both have opposite signs. He further deduced that any increase in GNP leads to a higher level of external debt, but overall external debt does not have any negative impact on economic growth.

Employing data from fifty-nine developing and twenty-four developed economies over a period of 1970 to 2002, Schclarek empirical result showed that external debt do not have significance in determining the economic performance of a country. However, a segment of his empirical especially on relationship between external debts and economic growth in developing countries showed that higher growth rate is associated with a relatively lower external debt levels and this inverse relationship is propelled by bilateral debts rather multilateral debts.

Mariano and Delano [4] employed the standard neo-classical growth model to test the dynamics of external debts, investments and economic growth for Philippines for over a period of 3 years $(2000$ to 2003). Using this model, the study asserted that higher ratio of change in interest rate spread to change in debt-to-GDP lowers welfare (economic growth and development index) in the long run.

In the study by Butts, which examined the effect of external debts (short-term only) and growth rate of GDP for 27 Latin-American countries for over a period of 33 years (1970-2003). The study found that granger causality only existed in thirteen (13) countries. Also, Geiger [5] conducted a study to check the effect of external debt on economic growth for nine (9) South American countries over a period of 12 years (1974-1986), and he found a statistically significant inverse relationship between the debt burden and economic growth.

Furthermore, Cohen [6] considered dataset of 81 developing countries with focus on a period of 1965-87 and his study concluded there is a positive relationship between external debt and economic growth. In another closely related study, Hasen adopted cross-country regression analysis examine causal effect of foreign aid and external debts on economic growth and investment level. The regression result showed that there is quite strong evidence of positive impact of aid both on the growth rate in GDP per capital and the investment rate not external debts.

Focusing on some of the HIPC countries, Were [7] analyzed the debt overhang problem in Kenya and tried to find evidence for its impact on economic growth. Using time series data from 1970 to1995, this study did not find any adverse impact of debt servicing on economic growth; however, it confirmed some crowding-out effects on private investment. 
Similarly, an investigation into the impact of external indebtedness on economic growth for Sudan, Mohamed used a time series data from 1978-2002. He used growth rate of real export earnings to capture the impact of export promotion strategy, while was used inflation to capture the impact of macroeconomic policy. He concluded that external debt and inflation deter economic growth, while, real exports have positive and significant impact on economic growth.

In Tanzania according to Oxfam [8] experience illustrated that the effects of debt of beyond finance to impact on the lives of vulnerable household. Given the limited domestic revenue available to government in Tanzania, the claims of foreign creditor reached alarming proportion while public sector external debt absorbs over $40 \%$ of domestic revenues.

Some previous studies in Nigeria on the relationship that existed between external debts and economic growth also have this mixed result. Jyoha [9] investigate the impact of external debt on economic growth in sub-Saharan African countries estimating a small macroeconometric model for the period 1970-2004. He found an inverse relationship between debt overhang, crowding out and investment, thereby concluding that external debt depresses investment through both a - disincentive effect and a - crowding out effect, thus affecting economic growth. Adepoju et al. [10] analyzed the time series data for Nigeria over a period from 1962 to 2006. Exploring time to time behavior of donor agencies as an outcome of various bilateral and multilateral arrangements, they concluded that accumulation of external debt hampered economic growth in Nigeria.

Hameed, et al. [11] explored the dynamic effect of external debt servicing, capital stock and labor force on the economic growth for Pakistan for a period of 1970-2003. They found an adverse effect of external debt servicing on labor and capital productivity which ultimately hampers economic growth. Ali and Mshelia found among others, both positive and negative relations with GDP, using Nigerian debt data.

Smyth and Hsing [12] have tried to test the federal government debts impact on economic growth and examine if an optimal debt ratio exists that will maximize the economic growth. The author calculated the optimal debt ratio (DEBT/GDPT), which represents the maximum real GDP growth rate (38.4\%). The DEBT/GDP ratio corresponding to the maximum GDP growth rate is $38.4 \%$.

\section{Nigeria Economic and External Debts Discussion}

The reliance on external financing for development has been an attribute of Nigeria since the pre-colonial era, as the first postindependence development plan of 1960-66 placed its finance on the shoulders of external countries and development institutions [13]. This background shows that accumulation of external debts is more practice that has been with the government for a long period of time. The dimension and the effect of external debts on economic performance of the country became important as the Oil boom of the 1970s and corresponding revenue from its sales didn't make Nigeria financial independent in financing developmental projects and initiatives [1416], as the post-civil war developmental plans of 1970-76 and the third of 1980-83 still have over $50 \%$ of the funds needed planed on external sources (Figures 1 and 2).

Nigerian government flamboyant lifestyle and high level of corruption coupled with various forms of misappropriation made the effect of the earnings from the black gold (Crude Oil) like effective in redirecting the fortune of the country's economic as it has been done with other countries blessed with same mineral resources by nature e.g United Arab Emirates, Saudi Arabia, Sweden, Denmark etc. During1980s with the global oil drought and high reliance of Nigerian government on crude oil as the major source of revenue, cum the total collapse of the tax system and non-functioning of the agricultural sector since the early 1970s made Nigerian government to be at the mercy of foreign governments, multinational financial institutions and international club of creditors (Paris and London Clubs) [17-20].

This trend is shown by Figure 1, as the GDP and external debts are positively related between 1981-1993, due to the incapacitation of the Nigeria to generate funds from other productive internal sources, and also, the condition is as bad as the Babaginda's regime accepting the adoption of the Structural Adjustment Programmes of the IMF even when the effects are obvious to the government [21]. The situation changed slightly due to the economic stand of the Abacha's Government, as there is a fail in the external debts accumulation and less reliance on external funds (Figures 3 and 4 ).

An upward movement in the level of external debts started with

\section{Economic Performance and External Debt Level of Nigeria (1981-} 2012)

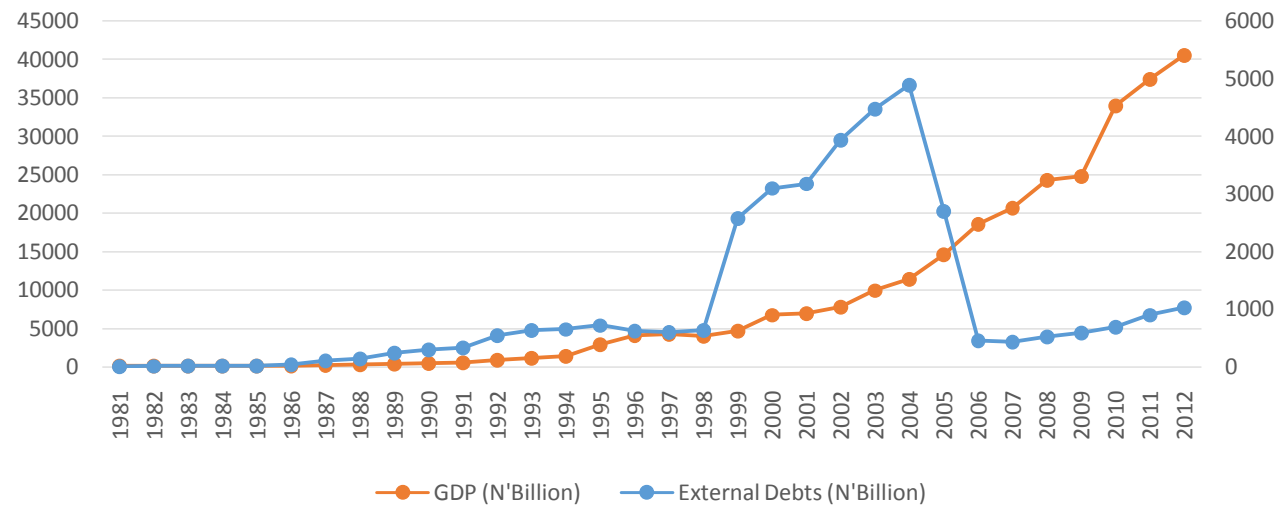

Source: Author using data from CBN Statistical Bulletin 2012.

Figure 1: Economics performance and debt level of Nigeria. 


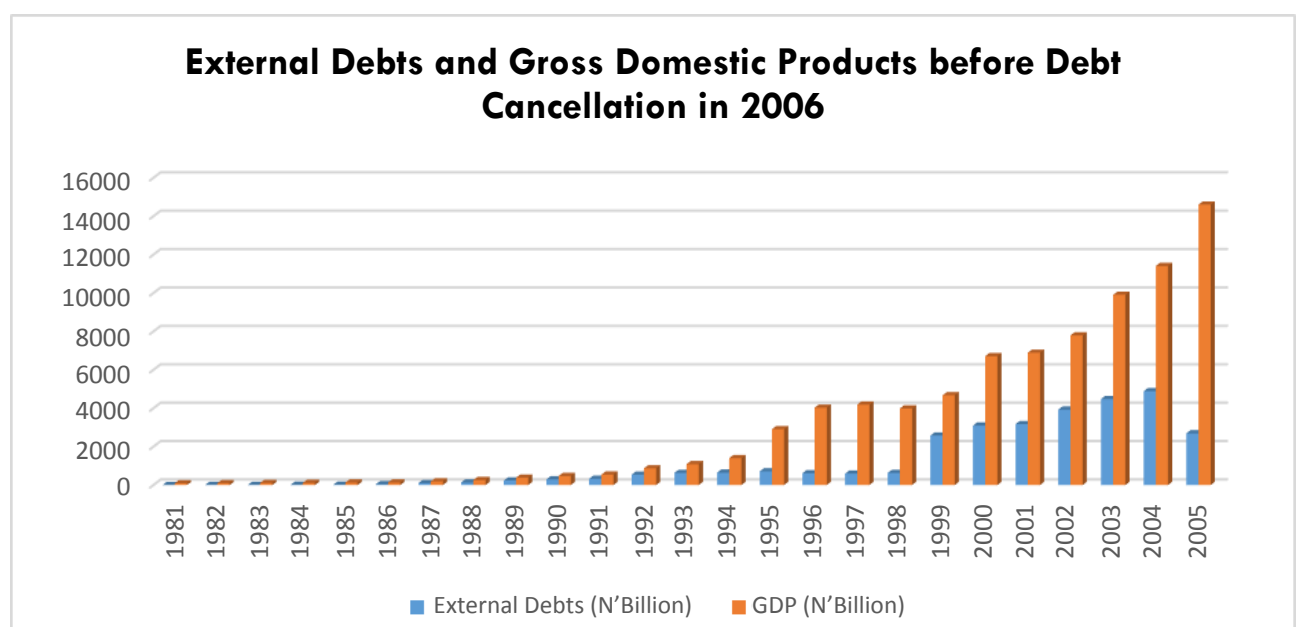

Source: Author using data from CBN Statistical Bulletin 2012

Figure 2: External Debts and Gross Domestic Products before Debt Cancellation in 2006.

\section{External Debts and Economic Growth After Debts Cancellation}

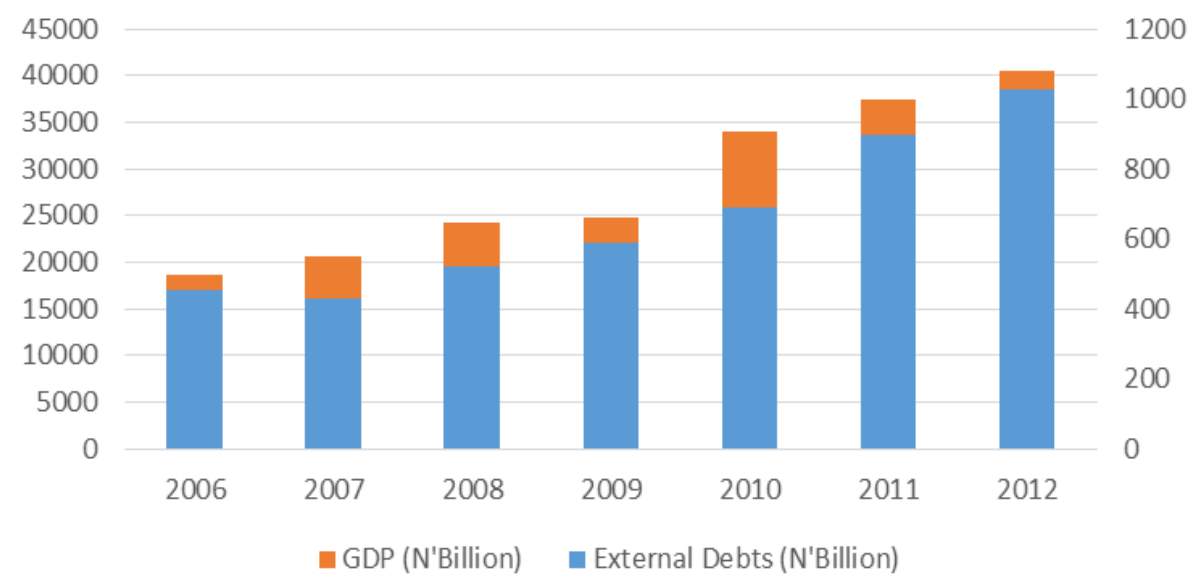

Source: Author using data from CBN Statistical Bulletin 2012.

Figure 3: External Debts and Economics Growth after Debts Cancellation.

the democratic regime before the debts cancellation of 2006, the debts was N633 Billion before Abacha while it increased to 2.58 trillion in 1999 and 4.89 trillion in 2004. With the fiscal policy of the Nigeria and commitment to payment of the accumulated debts as the total debts reduced to N2.7 trillion in 2005 while the debts cancellation by the London and Paris clubs of creditors reduced the debts to N451 million as at 2006 [18-20], thanks to the efforts of Dr. Ngozi Iweala's (then Minister of Finance). With this, the country has little debts burdens externally, but this debts only make the Nigerian government to only change sources of external debts while the external debts levels has increased at a sporadic rates of an annual increase more $20 \%$ since 2008. While loans from the (Figures 5-8).

London and Paris clubs are avoided, the country moved to taken loans from Multinational financial institutions, as before 2006 the share of these institution was below $20 \%$ but increased to over $80 \%$ in 2007 and as high as over $90 \%$ in 2010 while loans from other sources as grew significantly to $29 \%$ in 2012 and loans from the multinationals taking the remaining [22]. The rise in loans from these Multinationals posed a great threat to economic independence of Nigeria as incidence of economic imperialism are usually observed when a country rely on loans from these institutions, as the effect of structural adjustment programmes stiil live with us.

\section{Empirical Results}

\section{Data and preliminary analyses}

Table 1 section provides some preliminary analyses involving the description of relevant statistical properties of the variables under consideration. These analyses are carried in regards to the statistical distributions of the variables. From Table 1, it is shown that all the variables are positively skewed implying that the right tail is particularly extreme as the means of the variables are greater than their medians. Also, considering the Kurtosis, it shows that both GDP and external debts are leptokurtic which indicts that the distribution of the 


\section{BUDGET DEFICIT OF NIGERIA SINCE 2008}

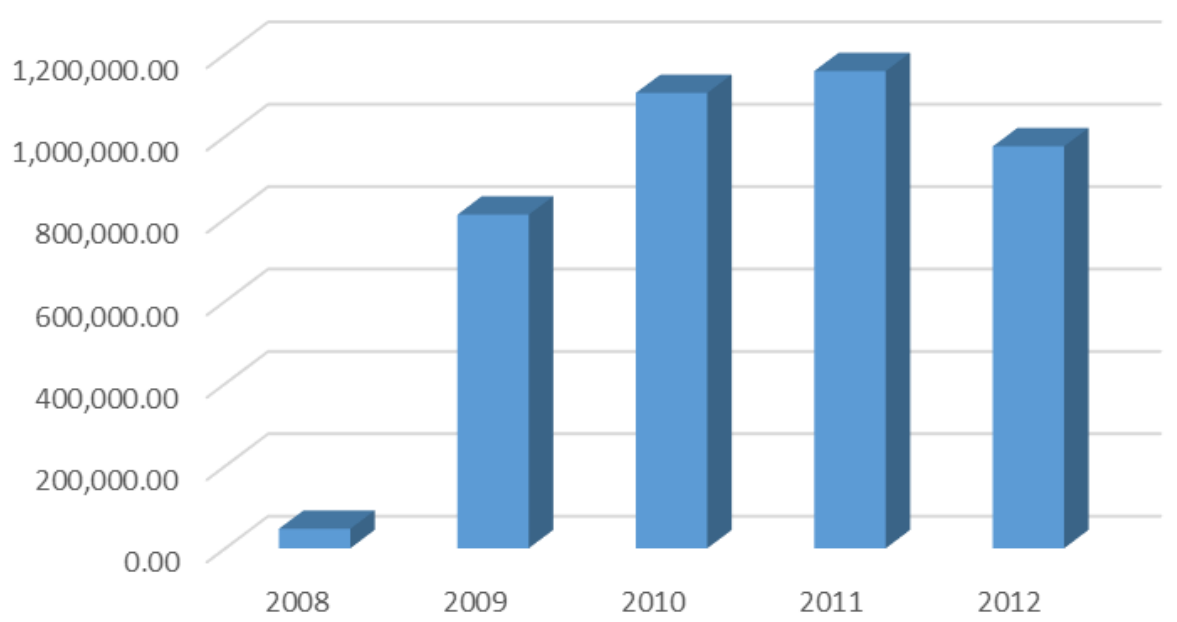

Source: Author using data from CBN Statistical Bulletin 2012

Figure 4: Budget Deficit of Nigeria since 2008

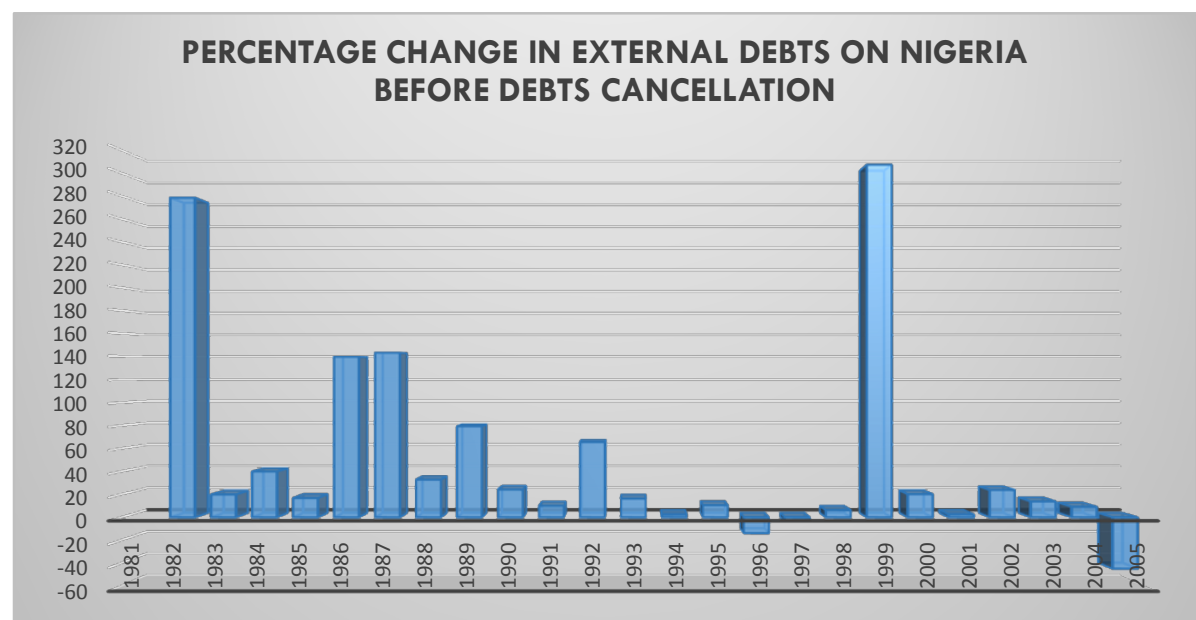

Source: Author using data from CBN Statistical Bulletin 2012.

Figure 5: Performance change in external debts on Nigeria before debts cancellation.

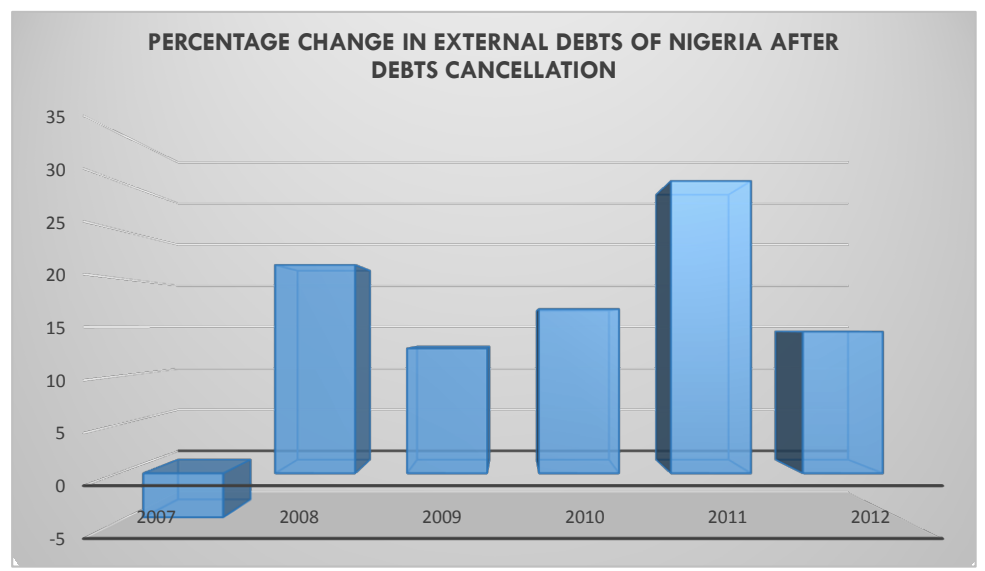

Source: Author using data from CBN Statistical Bulletin 2012

Figure 6: Performance change in external debts on Nigeria afterdebts cancellation. 
Citation: Olasode OS, Babatunde TS (2016) External Debts and Economic Growth in Nigeria: An Empirical Study Using Autoregressive Distributed Lag Model. Bus Eco J 7: 239. doi: 10.4172/2151-6219.1000239

Page 7 of 9

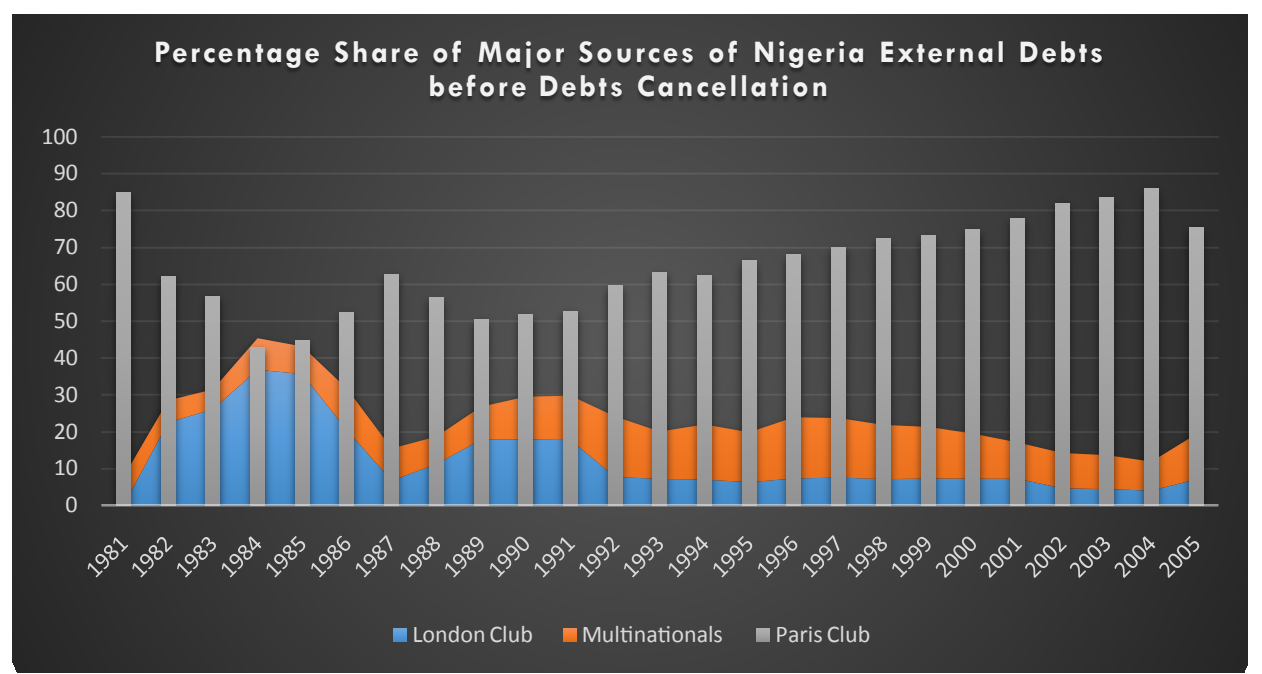

Source: Author using data from CBN Statistical Bulletin 2012

Figure 7: Percentage share of major sources of Nigeria External debts before debits cancellation.Source: Author using data from CBN Statistical Bulletin 2012.

\section{Percentage Share of Major Sources of Nigeria External Debts after Debts Cancellation}

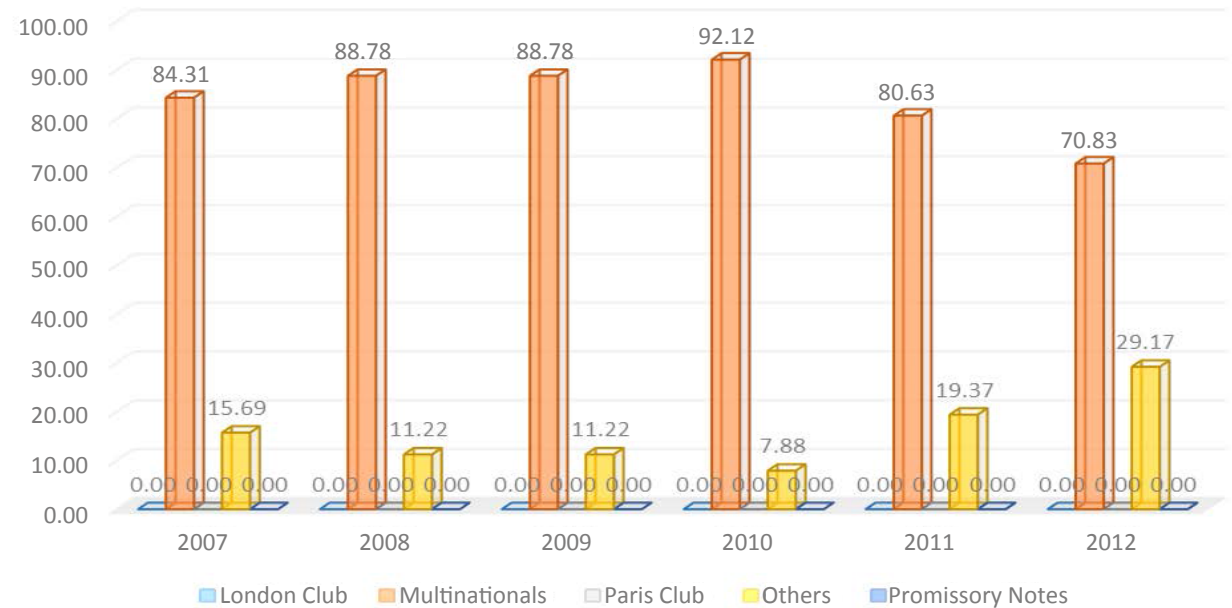

Source: Author using data from CBN Statistical Bulletin 2012

Figure 8: Percentage share of major sources of Nigeria external debts afterdebits cancellation.

\begin{tabular}{|l|c|c|}
\hline & EXT & GDP \\
\hline Mean & 1095134. & 8853167 \\
\hline Median & 593184.5 & 4010875 \\
\hline Maximum & 4890270. & 40544100 \\
\hline Minimum & 2331.200 & 94325.02 \\
\hline Std. Dev. & 1403332. & 11841431 \\
\hline Skewness & 1.517285 & 1.429400 \\
\hline Kurtosis & 3.964125 & 3.892411 \\
\hline Jarque-Bera & 13.51754 & 11.95884 \\
\hline Probability & 0.001161 & 0.002530 \\
\hline Sum & 35044282 & $2.83 \mathrm{E}+08$ \\
\hline Sum Sq. Dev. & $6.10 \mathrm{E}+13$ & $4.35 \mathrm{E}+15$ \\
\hline Observations & 32 & 32 \\
\hline
\end{tabular}

Source: Researchers' Computation from Eviews 7.

Table 1: Descriptive statistics. variables has a fat tails (in the case of leptokurtic distribution) than the normal distribution. Therefore, considering the overall normality test which is the use of Jarque Bera (JB) statistic shows evidence of nonnormality for all the variables as their JB-Statistics are greater than the critical value of 5.99 at $5 \%$ level of significance [23]. Therefore, the alternative inferential statistics that follow non-normal distributions are appropriate in this case.

\section{Unit root test}

As mentioned above, the first point of our analysis is to conduct the unit root test of stationarity using the Augmented Dickey-Filler (ADF) test. The result is presented in Table 2.

Decision Rule: Reject the null hypothesis if the $\mathrm{t}$-adf calculated is > the value of the two critical values; that is at $1 \%$ and $5 \%$. 


\begin{tabular}{|c|c|c|c|c|c|c|c|c|}
\hline \multirow[t]{2}{*}{ Variable } & \multirow[t]{2}{*}{ ADF } & \multicolumn{2}{|c|}{ Critical Values } & \multirow[t]{2}{*}{ Order of Integration } & \multirow[t]{2}{*}{ PP } & \multicolumn{2}{|c|}{ Critical Values } & \multirow{2}{*}{$\begin{array}{l}\text { Order of } \\
\text { Integration }\end{array}$} \\
\hline & & $1 \%$ & $5 \%$ & & & $1 \%$ & $5 \%$ & \\
\hline $\mathrm{EXT}^{* *}$ & -3.4459 & -4.2967 & -3.5684 & I(1) & -12.3494 & -4.3098 & -3.5742 & $\mathrm{I}(2)$ \\
\hline $\mathrm{GDP}^{* *}$ & -6.3542 & -4.2967 & -3.5684 & I(1) & -6.3569 & -4.2967 & -3.5684 & $\mathrm{I}(1)$ \\
\hline
\end{tabular}

**Significance at $5 \%$ and $1 \%$ levels and indicates the order of integration.

Source: Researchers' Computation from Eviews 7.

Table 2: Unit Roots Test (ADF AND PP Tests)

As shown in Table 3, the variables have different order of stationarity, some were stationary at first differenced while others at second differenced and some at both first and second differenced but no variable was stationary at level. That is, saying they are all integrated of order $1 \sim(1)$. Evidence of co-integration was shown from the order of integration presented above, which proves that the dependent variable has the same order with some of the explanatory variables. And for this reasons, we conduct co-integration test as shown below.

Also, considering the order of integration of the variables, the model will be adjustment to reflect this, as such, it will be re-specified and tested as:

\section{Co-integration test}

Given the unit root properties of the variables, we proceeded to implementing the Johasen co-integration procedure. Since the dependent variable has the same order of integration with some explanatory variables, we estimate their linear combination at level form without the intercept and obtain their residual, which is then subjected to cointegration test as shown below (Table 3).

The result presented in Table 2 above shows that there is presence of at least 2 co-integrating equations, which confirm the long-run relationship among the variables (Table 4).

\section{Economic Interpretation}

In the regression result, our Adjusted R-Square stood at $98.96 \%$ which is acceptable because the R-square must be above $60 \%$ to fit the data reasonably well on the regression line, provided that most of the important exogenous variables were captured by the model. The Adjusted R-square can be interpreted as our model being able to explain 98.96 per cent of the variation in Real Gross Domestic Product in the long run while the other 1.04 per cent was unaccounted for. The F-statistic shows that a joint or multiplicative relationship existed between External Debt and GDP and also, the external debts has an impact on economic growth in Nigeria.

From the findings above, coefficients of Gross Domestic Products for previous year, GDP (-1) and External Debts for previous year, EXT $(-1)$ are positive indicating that are incentives for economic growth in Nigeria. While the external debts (Ext) has a negative impact on economic growth in Nigeria. According to the result, with holding all other variables constant, a unit increase in Gross Domestic Products for previous year, $\operatorname{GDP}(-1)$ and External Debts for previous year, EXT(-1) will increase economic growth of present year by 1.193730 Millions and 0.579473 Million respectively. While a similar fate for external debts at present year will lead a decrease of 0.348114 Million, which can be adduced to the fact most of the loans taken from external sources never get utilized in the same year, as these money are usually keep in some accounts to yield interest for those in government, as a result it impacts on the economy negatively the year it was taken.

Following Gujarati, to find out whether the model is adequate and well specified, we use the F-test such that if F-statistics is greater than 0.05 at $5 \%$ level of significance, the model is considered good

\begin{tabular}{|c|c|c|c|c|}
\hline \multicolumn{5}{|c|}{ Date: 03/27/14 Time: 12:16 } \\
\hline \multicolumn{5}{|c|}{ Sample (adjusted): 19832012} \\
\hline \multicolumn{5}{|c|}{ Included observations: 30 after adjustments } \\
\hline \multicolumn{5}{|c|}{ Trend assumption: Linear deterministic trend } \\
\hline \multicolumn{5}{|c|}{ Series: EXT GDP } \\
\hline \multicolumn{5}{|c|}{ Lags interval (in first differences): 1 to 1} \\
\hline Hypothesized & & Trace & $5 \%$ & $1 \%$ \\
\hline No. of CE(s) & Eigenvalue & Statistic & Critical Value & Critical Value \\
\hline None $^{* *}$ & 0.536370 & 28.30553 & 15.41 & 20.04 \\
\hline At most $1^{*}$ & 0.160416 & 5.245480 & 3.76 & 6.65 \\
\hline \multicolumn{5}{|c|}{ Trace test indicates 2 cointegrating equation(s) at the $5 \%$ level } \\
\hline \multicolumn{5}{|c|}{ Trace test indicates 1 cointegrating equation(s) at the $1 \%$ level } \\
\hline \multicolumn{5}{|c|}{$\left.{ }^{*}{ }^{* *}\right)$ denotes rejection of the hypothesis at the $5 \%(1 \%)$ level } \\
\hline Hypothesized & & Max-Eigen & 5 Percent & 1 Percent \\
\hline No. of CE(s) & Eigenvalue & Statistic & Critical Value & Critical Value \\
\hline None $^{* *}$ & 0.536370 & 23.06005 & 14.07 & 18.63 \\
\hline At most $1^{*}$ & 0.160416 & 5.245480 & 3.76 & 6.65 \\
\hline \multicolumn{5}{|c|}{ Max-eigenvalue test indicates 2 cointegrating equation(s) at the $5 \%$ level } \\
\hline \multicolumn{5}{|c|}{ Max-eigenvalue test indicates 1 cointegrating equation(s) at the $1 \%$ level } \\
\hline${ }^{*}\left({ }^{* *}\right)$ denotes rej & on of the $h$ & & & \\
\hline
\end{tabular}

Table 3: Johansen co-integration tests.

\begin{tabular}{|c|c|c|c|c|}
\hline \multicolumn{5}{|c|}{ Dependent Variable: GDP } \\
\hline \multicolumn{5}{|l|}{ Method: Least Squares } \\
\hline \multicolumn{5}{|c|}{ Date: 03/27/14 Time: $12: 28$} \\
\hline \multicolumn{5}{|c|}{ Sample (adjusted): 19832012} \\
\hline \multicolumn{5}{|c|}{ Included observations: 30 after adjustments } \\
\hline Variable & Coefficient & Std. Error & t-Statistic & Prob. \\
\hline C & -503049.3 & 454318.7 & -1.107261 & 0.2787 \\
\hline $\operatorname{GDP}(-1)$ & 1.193730 & 0.037217 & 32.07506 & 0.0000 \\
\hline EXT & -0.348114 & 0.354143 & -0.982974 & 0.3350 \\
\hline EXT(-1) & 0.579473 & 0.352713 & 1.642904 & 0.1129 \\
\hline $\operatorname{ECM}(-1)$ & -0.532568 & 0.211272 & -2.520771 & 0.0185 \\
\hline R-squared & 0.989600 & \multicolumn{2}{|c|}{ Mean dependent var } & 9436867. \\
\hline Adjusted R-squared & 0.987936 & \multicolumn{2}{|c|}{ S.D. dependent var } & 12010434 \\
\hline S.E. of regression & 1319192. & \multicolumn{2}{|c|}{ Akaike info criterion } & 31.17395 \\
\hline Sum squared resid & $4.35 E+13$ & \multicolumn{2}{|c|}{ Schwarz criterion } & 31.40748 \\
\hline Log likelihood & -462.6092 & \multicolumn{2}{|c|}{ Hannan-Quinn criter. } & 31.24866 \\
\hline F-statistic & 594.7013 & \multicolumn{2}{|c|}{ Durbin-Watson stat } & 2.294594 \\
\hline Prob(F-statistic) & 0.000000 & & & \\
\hline
\end{tabular}

Source: Researchers's Computation from EViews 7. $R^{2}=0.989600, D W=2.294594$.

Table 4: Autoregressive distributive lag regression result.

and adequate for forecasting and policy analysis. From the result, Prob. (F-statistic) is 0.00000 at $5 \%$ level of significance implying that the model is well specified and can be used to forecast and as well as it usage for policy analysis. And finally the Durbin-Watson value 2.294594 indicates absence of positive Serial Auto-correlation among the variables used in the model. Also, the ECM has the right sign and also significant indicating validity of a run long-run adjustment in the model. Hence, the coefficient of ECM shows that $53.26 \%$ of disequilibrium in last year's estimation is corrected in the following year. 
Citation: Olasode OS, Babatunde TS (2016) External Debts and Economic Growth in Nigeria: An Empirical Study Using Autoregressive Distributed Lag Model. Bus Eco J 7: 239. doi: 10.4172/2151-6219.1000239

\section{Conclusion and Policy Recommendations}

External debt is a fraction of the country's national debt sourced from foreign individuals, agencies or government. It has been observed and confirmed by this study that external debt contribute in both positive and negative way to economic growth in Nigeria. Therefore, the question of the positive contributions outweighing the negative contributions is not a subject of this research work. It is a clear fact from observable reality that ineffective utilization of debt will make repayment a difficult task, the interest will keep accruing (a time almost to the tune of the capital), then repayment becomes a problem and such debt will become a bad debt.

The findings however revealed that external debt contributed positively and negatively to growth and development process of Nigeria which is determined by the time in question. The study used GDP as a proxy for economic growth under the assumption that gross domestic product is a measure of productivity of a country, hence economic growth. In the light of the above summary, observations and conclusion, this study hereby makes the following policy recommendations:

- The modalities of incurring external debt and their application should be technically and tactically analyzed prior to accessing the debt, as external debts in the first year of receipts tends to have a negative impact on the Nigerian economy.

- Although, External debts are meant to boost the economic growth and development of the debtor country and improve the standard of living of the citizenry, as such Nigerian government should ensure that debts incurred are channel towards productive uses and sourcing external debts should be considered as a means of long run development not just for solving short run problems.

- In line with this, the Debt Management Office should strengthen their plans and ensure that external loans be taken only if needed in critical capital areas that must be strictly monitored. And other areas of financing such as Concession by foreign governments and financial institutions should be pursue.

- Nigeria should use her accumulated external foreign reserves instead of incurring more external debts, as this will ensure increase in real economic growth and reduce capital flights through repayments of debts to external sources.

\section{References}

1. Pattilo C, Ricci L, Poirson H (2001) Non-linear Impact of External Debt Growth. Journal of Policy Modeling 31: 272-288.

2. Jakob C (2004) Domestic Debt Market in Sub-Saharan in Africa. International Monetary Fund Macroeconomic Stability, Washington.
3. Abbas-Ali SM, Jakob C (2007) The Role of Democratic Debt Markets in Economic. IMF working paper.

4. Mariano RS, Delano V (2006) External Debt, Adjustment, and Growth Singapore management university.

5. Geiger LT (1990) Debit and Economic Development in Latin America. The Journal of Developing Areas 24: 181-194.

6. Cohen D (1993) Growth and External Debt. CEPREMAP

7. Were M (2001) The impact of External Debt on Economic Growth in Kenya: An Empirical Assessment. UNU-WIDER Research Paper.

8. Oxfam W (1998) Pastoral Development Project: An Economic Impact Assessment. University of Nairobi.

9. Iyoha MA (1999) External debt and economic growth in Sub-Saharan Africa countries. Journal of African Economic Research 90: 15-18.

10. Adepoju AA, Salau AS, Obayelu AE (2007) The effects of External Debt management on Sustainable Economic Growth and Development: Lessons from Nigeria. Econ papers.

11. Hameed A, Hammad A, Muhammed AC (2008) External Debts and its Impact on Economic and Business Growth in Pakistan. International Research Journal of Finance and Economics 20:132-140.

12. Smyth DJ, Hsing $Y$ (1995) In Search of an Optimal Debt Ratio for Economic Growth. Contemporary Economic Policy 13: 51-59.

13. Anyanwu JC, Oyefusi A, Oaikhenan H, Dimowo FA (1997) the structure of the Nigeria Economy. Onitsha Anambra: Joanee Educational Publishers Ltd.

14. Ayadi FS (1999) The impact of External Debt Servicing requirements on Nigeria's Economic Development. University of Lagos, Nigeria.

15. Ayadi FS, Ayadi FO (2008) The impact of external debt on economic growth: A comparative study of nigeria and south Africa. Journal of sustainable Development in Africa 10: 234-264.

16. Ayadi FS, Toluwase A, Ayadi OF, Chatterjee A (2003) Investment Asjustment mechanism and External Debt burden in a Developing Economy. Dimension of African Business and Development, south Yorkshire: Sheffield Hallam University Press.

17. Ayadi FS, Ayadi FO (2008) The Impact of External Debt on Economic Growth A comparative Study of Nigeria and South Africa. Journal of Sustainable Development in Africa, University of Lagos.

18. Central Bank of Nigeria, Annual Report and Statement of Accounts, CBN Nigeria Various Issues (2012).

19. Central Bank of Nigeria, Statistical Bulletin, CBN Nigeria, Various Issues (2012)

20. Central Bank of Nigeria Statistical Bulletin 2012

21. Chowdhury AR (2004) External Debt, Growth and the HIPC initiative: Is the country choice too narrow? New York: Palgrave Macmillan.

22. Chowdhury K (1994) A structural Analysis of External Debt and Economic Growth: Some Evidence from selected countries in Asia and the pacific. Applied Economics 26: 1121-1131.

23. Pattilo C, Poirson H, Ricci L (2002) External Debt and Growth. IMF working paper 